\title{
Listy Mikołaja Radziwiłła „Rudego”, wojewody wileńskiego, do bratanka, Mikołaja Krzysztofa ,Sierotki”: grudzień 1568 - czerwiec 1569 r. Ze zbiorów Rosyjskiej Biblioteki Narodowej w Sankt-Petersburgu
}

W Rosyjskiej Bibliotece Narodowej w Sankt-Petersburgu w fondzie 971 znajduje się oryginalna, bardzo interesująca korespondencja Mikołaja Radziwiłła „Rudego”, którą prowadził z Mikołajem Krzysztofem Radziwiłłem „Sierotką”, najstarszym synem brata stryjecznego, Mikołaja Radziwiłła „Czarnego”.

Mikołaj Radziwiłł „Rudy” był bratem rodzonym królowej Barbary Radziwiłłówny, drugiej żony Zygmunta Augusta. Miał ogromne zasługi na polu militarnym, szczególnie w hamowaniu apetytów moskiewskich na terenie Inflant, ale i w obronie rodzimych terenów litewskich w walce z Moskwą. Od 1556 r. używał tytułu najwyższego hetmana litewskiego, w czym Henryk Lulewicz widzi sygnał dla trwałości wykonywania w tym okresie przez Mikołaja Radziwiłła „Rudego" funkcji hetmańskiej². Brał aktywny udział w życiu publicznym Wielkiego Księstwa Litewskiego. Od 1549 r. był „nieformalnym namiestnikiem monarchy na Litwie, z bardzo szerokimi uprawnieniami"'s. Trwało to do czerwca $1551 \mathrm{r}$., gdy Mikołaj Radziwiłł „Czarny” uzyskał od Zygmunta Augusta urząd wojewody wileńskiego, utrzymując nadal marszałkostwo i kanclerstwo. W tymże roku król przekazał pod jego opiekę archiwum państwa litewskiego ${ }^{4}$. Wówczas to brat stryjeczny Barbary Radziwiłłówny wysunął się na czoło elit Wielkiego Księstwa Litewskiego. Dominacja Mikołaja Radziwiłła „Czarnego” na litewskiej scenie politycznej trwała aż do jego śmierci w $1565 \mathrm{r}$. Bracia konkurowali wprawdzie ze sobą w sprawach związanych z łaską monarszą, byli zgodni jednak co do dwóch

1 H. Lulewicz, Radziwitt Mikołaj zwany Rudym, h. Trąy (1512-1584), wojewoda trocki, hetman najwyższy litewski, potem wojewoda wileński i kanclerz litewski, syn Jerzego $i$ Barbary Kolanki, [w:] Polski Stownik Biograficzny (dalej: PSB), t. 30, s. 321-325; M. Ferenc, Mikotaj Radziwitt „Rudy” (ok. 1515-1584). Działalność polityczna i wojskowa, Kraków 2008.

2 H. Lulewicz, op. cit., s. 323-326.

3 M. Ferenc, op. cit., s. 107.

4 [E. Kotłubaj], Galeria Nieświeżska portretów radziwiłłowskich, Wilno 1857, s. 237. 
zasadniczych spraw dotyczących państwa litewskiego i własnego domu: byli stałymi przeciwnikami utraty dotychczasowego statusu prawnoustrojowego Wielkiego Księstwa Litewskiego i - mimo niejednokrotnych sprzeczności interesów - widzieli konieczność wzajemnego wspierania się w kwestii umacniania pozycji domu Radziwiłłów. Współdziałali także w opozycji wobec Jana Radziwiłła, rodzonego brata Mikołaja Radziwiłła „Czarnego”, który optował za realizacją unii Wielkiego Księstwa z Koroną we współpracy z królową Boną i rzecznikami ściślejszego związku obu państw5.

Mikołaj Radziwiłł „Rudy” został wyznaczony przez brata stryjecznego do grona opiekunów małoletnich dzieci pozostałych po śmierci Mikołaja Radziwiłła „Czarnego” w 1565 r., obok Mikołaja Paca biskupa kijowskiego, Jana Krzysztofa Tarnowskiego wojewody wojnickiego, Konstantego Wasyla Ostrogskiego wojewody kijowskiego, marszałka ziemi wołyńskiej, Ostafiego Wołłowicza, podskarbiego ziemskiego Wielkiego Księstwa Litewskiego ${ }^{6}$.

Mikołaj Krzysztof Radziwiłł „Sierotka” ${ }^{\prime}$ był najstarszym synem Mikołaja Radziwiłła „Czarnego" i Elżbiety z Szydłowieckich. W chwili gdy nastąpiła śmierć jego ojca (28/29 maja 1565 r.), przebywał na studiach za granicą (od lipca 1563 r.) $)^{9}$. Jego trzej małoletni bracia: Jerzy ${ }^{10}$, Albrecht ${ }^{11}$ i Stanisław ${ }^{12}$, a także siostry: Elżbieta, Zofia, Anna i Krystyna pozostawali pod opieką prawną grona opiekunów. Księżniczki Radziwiłłówny po śmierci ojca przebywały na dworze Zofii z Odrowążów Tarnowskiej, żony Jana Krzysztofa Tarnowskiego, wojewody wojnickiego. Bracia Mikołaja Krzysztofa do jego powrotu ze studiów, osiągnięcia pełnoletności i formalnego przejęcia opieki nad rodzeństwem przez najstar-

5 M. Ferenc, op. cit., s. 119-123; M. Michalewiczowa, Radziwiłt Jan, h. Trąby (1516-1551), krajczy litewski, [w:] PSB, t. 30, s. 195-197.

6 Testament Mikołaja Czarnego Radziwiłła, [w:] J. Jasnowski, Mikołaj Czarny Radziwiłt (1515-1565), kanclerz i marszałek ziemski Wielkiego Księstwa Litewskiego, wojewoda wileński, „Rozprawy Historyczne Towarzystwa Naukowego Warszawskiego", t. 22, Warszawa 1939, s. 415-418; U. Augustyniak, Testamenty ewangelików reformowanych $w$ Wielkim Księstwie Litewskim, Warszawa 1992, s. 16-21.

7 H. Lulewicz, Radziwitt Mikołaj Krzysztof „Sierotka”, h. Traby (1549-1616) marszatek nadworny, następnie wielki litewski, kasztelan, potem wojewoda trocki, wojewoda wileński, [w:] PSB, t. 30, s. 349-361; T. Kempa, Mikotaj Krzysztof Radziwitt Sierotka (1549-1616), wojewoda wileński, Warszawa 2000.

8 H. Lulewicz, Radziwitt Mikołaj zwany Czarnym, h. Trąby (1515-1565), [w:] PSB, t. 30, s. 335-347; J. Jasnowski, op. cit.

9 T. Kempa, op. cit., s. 31.

10 W. Müller, Radziwiłt Jerzy, h. Trąby (1556-1600), biskup wileński, gubernator Inflant, kardynat, biskup krakowski, [w:] PSB, t. 30, s. 229-234.

11 H. Lulewicz, Radziwitt Albrycht, h. Trąby (1558-1592), marszałek nadworny litewski, potem wielki, [w:] PSB, t. 30, s. 135-139.

12 Idem, Radziwiłt Stanisław, h. Trąby (1559-1599), marszałek wielki litewski, następnie starosta żmudzki, [w:] PSB, t. 30, s. 363-367. 
szego z synów Mikołaja Radziwiłła „Czarnego”, pozostawali prawdopodobnie na dworze stryja, Mikołaja Radziwiłła „Rudego”. Życzył sobie tego ich ojciec we wspomnianym testamencie. W 1571 r. młodsi bracia Mikołaja Krzysztofa udali się na studia zagraniczne ${ }^{13}$. Ich dobra po powrocie najstarszego z braci do kraju pozostawały w jego zarządzie. Do podziału spuścizny po Mikołaju Radziwille „Czarnym” doszło po powrocie młodszego rodzeństwa z zagranicy, 4 grudnia 1577 r. ${ }^{14}$ A więc Mikołaj Krzysztof Radziwiłł „Sierotka” miał do tego momentu dobra braterskie pod swoją opieką. Jest to szczególnie istotne, jeśli się zważy, że dobra dziedziców posiadłości Mikołaja Radziwiłła „Czarnego” były położone między innymi na spornym między Księstwem Litewskim i Polską Podlasiu i Wołyniu. A odpowiedzialność najstarszego z synów Mikołaja Radziwiłła „Czarnego” za majętności nieletnich braci była tym większa, iż na pewno istniało w pamięci rodzinnej nieporozumienie na tle podziału majątkowego między ich ojcem, Mikołajem Radziwiłłem „Czarnym”, a jego rodzonym bratem, Janem, krajczym litewskim, z wszystkimi konsekwencjami, negatywnymi dla jedności domu ${ }^{15}$.

Listy wojewody wileńskiego pisane są w okresie bardzo ważnym dla obu państw, w okresie sejmu, tzw. unijnego, kończącego długotrwałe starania Zygmunta Augusta i elit koronnych o unifikację Korony i Wielkiego Księstwa Litewskiego ${ }^{16}$.

Problem formy związku obu państw jagiellońskich: unii zawartej 1 lipca 1569 r., dotąd odmiennie jest postrzegany przez historyków litewskich i polskich ${ }^{17}$. Ostatnio otrzymaliśmy spojrzenie angielskiego historyka na problemy unii zawieranych przez Polskę i Wielkie Księstwo Litewskie ${ }^{18}$. Tym bardziej warto przyjrzeć się stanowisku wobec zacieśnień związku z Polską czołowej postaci życia politycznego państwa litewskiego, jakim niewątpliwie był Mikołaj Radziwiłł „Rudy”.

Zarówno Mikołaj Radziwiłł „Czarny”, jak i jego stryjeczny brat, Mikołaj Radziwiłł „Rudy”, byli przez wiele lat przeciwnikami unifikacji ustrojowo-politycznej obu państw jagiellońskich. Było to zgodne z polityką Zygmunta

13 T. Kempa, op. cit., s. 46.

14 H. Lulewicz, Radziwitt Albrycht..., s. 136.

15 M. Ferenc, op. cit., s. 122-123; M. Michalewiczowa, op. cit., s. 195-197.

16 Sejm walny lubelski 1569 r., [w:] Volumina Constitutionum [dalej: VC], t. II: 1550-1609, vol. 1: 1550-1585, przygotowali do druku: S. Grodziski, I. Dwornicka, W. Uruszczak, Warszawa 2005, s. $213-268$.

17 A. Rachuba, J. Kiaupienie, Z. Kiaupa, Historia Litwy. Dwugłos polsko-litewski, Warszawa 2008; Z. Kiaupa, J. Kiaupienie, A. Kuncevičius, Historia Litwy. Od czasów najdawniejszych do 1795 roku, Warszawa 2007, s. 228-229.

18 R. Frost, The Oxford History of Poland-Lithuania, vol. 1: The Making of the Polish-Lithuanian Union, 1385-1569, Oxford 2015. 
Augusta w okresie gdy jego żoną była Barbara Radziwiłłówna i potem, gdy miał nadzieję na potomstwo z trzecią żoną, Katarzyną Habsburżanką. Obaj wspomniani Radziwiłłowie i monarcha ściśle współpracowali w zwalczaniu opozycji antyradziwiłłowskiej i antyksiążęcej, skłonnej do współpracy z tymi siłami politycznymi w Koronie, które w programie politycznym zawierały zacieśnienie związku obu państw. Mimo tego, iż król zmienił swoje stanowisko w kwestii prawnego uregulowania zespolenia obu państw od początku lat sześćdziesiątych XVI stulecia, bracia Radziwiłłowie nadal byli nieprzejednanymi przeciwnikami unii. W warstwie deklaratywnej, w pierwszej kolejności chodziło im o zachowanie odrębności państwowej. Nie było to jedynym wytłumaczeniem ich oporu przeciwko realizacji unii. Wysoka pozycja społeczna panów litewskich wynikająca z przywilejów prawnych, gospodarczych i politycznych, jakie posiadali w pierwszej połowie XVI w., była w wyraźny sposób zagrożona w przypadku gdy polityczno-ustrojowe prawa koronne przeniesione zostałyby na terytorium Wielkiego Księstwa Litewskiego.

Domaganie się ściślejszego związku obu państw jagiellońskich przez elity litewskie, opozycyjne wobec dominacji radziwiłłowskiej w Wielkim Księstwie Litewskim, datują się od początku lat pięćdziesiątych XVI w. (Chodkiewiczowie, Grzegorz Ościkowicz Wierszyłł, Hlebowiczowie, Iwan Hornostaj). Były one jednak tak słabe w stosunku do potęgi radziwiłłowskiej, iż na jesiennym sejmie litewskim w 1551 r. gremium to nie było w stanie zmusić elit litewskich do dyskusji nad projektem unifikacji, przywiezionym do Wilna przez Jana Ocieskiego, podkanclerzego koronnego. W wizji króla w owym czasie unia powinna przyjąć charakter ścisłego przymierza wojskowego. Na tymże sejmie litewskim Zygmunt August czasowo uspokoił Mikołajów „Czarnego” i „Rudego” Radziwiłłów, potwierdzając wszystkie dotychczasowe prawa Wielkiego Księstwa Litewskiego ${ }^{19}$.

Sytuacja geopolityczna, w jakiej znalazło się państwo litewskie od końca lat pięćdziesiątych XVI stulecia (zagrożenie państwa ze strony Iwana IV Groźnego i problem braku bezpieczeństwa Inflant z racji interesów Moskwy, Danii i Szwecji na tych terenach) wymagały natychmiastowego zaangażowania militarnego wojsk koronnych. Wojskowa pomoc polska dla Wielkiego Księstwa Litewskiego w XVI w. nie była niczym nowym. Już podczas walk króla Aleksandra i Zygmunta I na wschodzie, w odparciu zakusów wschodniego sąsiada Wielkiego Księstwa, brały udział oddziały koronne. Wysiłek ten stanie się inspiracją dla postulatów unifikacyjnych, wychodzących nie tylko z kręgów aktywnej politycznie szlachty koronnej, dążącej do reform, ale także i możnowładztwa polskiego. Z kolei zaangażowanie bojarstwa litewsko-ruskiego w walkę o zachowanie integralności terytorialnej państwa litewskiego pobudzi rycerstwo Wielkiego Księstwa

19 J. Jasnowski, op. cit., s. 56-57, 74-75. 
Litewskiego do walki o uzyskanie statusu prawnego, takiego samego jak miała szlachta koronna: równości wobec prawa wszystkich przelewających krew dla dobra państwa. Jak trafnie zauważył Marek Ferenc, także koligacenie się rodów litewsko-ruskich z domami koronnymi i wobec tego związki rodzinne, z wszelkimi konsekwencjami kulturowo-politycznymi (także paradoksalnie związki małżeńskie rodu Radziwiłłów), przyspieszały dojrzewanie społeczności obu państw do realizacji unii ${ }^{20}$. Pomoc wojsk koronnych w odparciu zagrożenia moskiewskiego uzyskała między innymi akceptację posłów polskich podczas sejmu piotrkowskiego w 1555 r. W zamian szlachta koronna domagała się unii z Wielkim Księstwem Litewskim. Zająć się tą sprawą miał kolejny sejm, zwołany na listopad 1556 r. ${ }^{21}$ Zagrożenie interesów litewskich w Inflantach nie pozwoliło jednak na zajęcie się sprawą unifikacji państw jagiellońskich. Włączenie się kwestii Inflant do polityki zagranicznej Wielkiego Księstwa Litewskiego nastąpiło po zawarciu układu wileńskiego z Gerardem Kettlerem w 1559 r. Mimo iż Inflantczycy chcieli przyłączenia Inflant do obu państw jagiellońskich, panowie litewscy dali do zrozumienia, iż są w stanie sami obronić te tereny ${ }^{22}$. Brak dostatecznych możliwości obronnych państwa litewskiego do utrzymania Inflant, zrozumienie panującego dla zagrożenia interesów obu tych państw w basenie Morza Bałtyckiego, gdyby wkroczyły na te tereny Moskwa, Szwecja i Dania, rozszerzyło konieczność współpracy militarnej. Miało to ścisły związek z ewolucją poglądów króla na temat prawnego utrwalenia współpracy obu państw w długiej perspektywie chronologicznej.

Kolejny układ ze stanami inflanckimi z 1561 r. zakładał poddanie się Inflant Zygmuntowi Augustowi jako królowi polskiemu i wielkiemu księciu litewskiemu. Król zobowiązał się, iż po uzyskaniu zgody stanów wcieli je jednak w skład Korony ${ }^{23}$.

Problem obrony Inflant, niemożliwy, jak się okazało, bez udziału sił zbrojnych i wsparcia finansowego wojny przez Koronę widoczny był szczególnie w 1562 r. W marcu wygasł rozejm z Moskwą, a już w następnych miesiącach wojska Iwana IV najechały terytorium księstwa (rejon Orszy, Witebska i Szkłowa) ${ }^{24}$. Wprawdzie w odwecie wojska polskie pod dowództwem Floriana Zebrzydowskiego i litewskie, na czele których stanął Stanisław Dowojna, wyhamowały zapędy moskiewskie na te tereny, tym niemniej niebezpieczeństwo najazdu księcia moskiewskiego zarówno na Inflanty, jak i na tereny państwa litewskiego, wymagało porozumienia $\mathrm{z}$ Polakami. A w skład programu reform proponowanych przez

\footnotetext{
20 M. Ferenc, op. cit., s. 144.

21 J. Jasnowski, op. cit., s. 127.

22 Ibidem, s. 250.

23 Ibidem, s. 291-292.

24 A. Sucheni-Grabowska, Zygmunt August król polski i wielki książe litewski 1520-1562, Warszawa 1996, s. 408.
} 
rycerstwo wchodziła unifikacja terytorialno-ustrojowa państw pozostających pod panowaniem Zygmunta Augusta. Niebezpieczeństwo ze strony Moskwy, Szwecji i Danii w Inflantach nie było jednak jedynym impulsem dla opowiedzenia się króla za unią. Reformy, jakich dokonano z jego inicjatywy w Księstwie Litewskim (uporządkowanie administracji terytorialnej i wprowadzenie powiatów jako głównej jednostki podziału administracji państwowej, sejmiki powiatowe i rozszerzenie kompetencji sejmu na wzór polski, przekształcenie rady panów w senat, zniesienie egzempcji sądowniczej panów litewskich i wprowadzenie jednorodnego sądownictwa na wzór koronny, a w końcu: rezygnacja z dziedziczności tronu hospodarskiego, umożliwiająca w przyszłości wspólną elekcję monarchy $)^{25}$, w widoczny sposób przygotowywały państwo litewskie do ścisłego związku i wspólnego funkcjonowania z Polską.

Wsparcie dla idei unii w tym czasie wyszło także z kręgów rycerstwa litewskiego, zmęczonego dotkliwymi ciężarami wojskowymi i poborowymi. Na zjeździe w Witebsku, jesienią 1562 r., korzystając z wyjazdu Mikołaja Radziwiłła „Rudego”, do dotychczasowych postulatów włączyła szlachta litewska punkt dotyczący konieczności zwołania wspólnego Koroniarzy z Litwinami sejmu, na którym opracowano by zasady unii (wspólnej obrony, wspólnego obioru panującego, wspólnego sejmu i wspólnego prawa). Oskar Halecki pisze o zawiązaniu w tym momencie konfederacji wymierzonej przeciwko przeciwnikom unii ${ }^{26}$. Siłą rzeczy elity możnowładcze musiały zacząć się liczyć, w kontekście zagrożeń zewnętrznych, ze zdaniem rycerstwa swego państwa. $Z$ drugiej strony, warto pamiętać, iż szlachta litewska, podobnie jak możnowładztwo, nie chciała utracić odrębności „swojej” Rzeczypospolitej.

Sejm piotrkowski z 1562/1563 r. zajął się przede wszystkim realizacją programu egzekucji dóbr i praw. Po dotarciu informacji o utracie Połocka (wieść o tej klęsce dotarła do Piotrkowa 25 lutego 1563 r.), w solidarności z królem odpowiedzialnym za integralność Wielkiego Księstwa, w poczuciu wspólnoty wielowiekowych związków z państwem litewskim, i w świadomości przyszłego ewentualnego zagrożenia własnego państwa, Polacy uchwalili podatki na wojnę toczoną ze wschodnim sąsiadem ${ }^{27}$. Klęska połocka przyspieszyła niewątpliwie dojrzewanie do zawarcia ściślejszego niż dotąd związku państw jagiellońskich wszystkich gremiów, wahających się dotąd. Kształt tego związku czekała jednak droga pełna wybojów. Podstawowy problem przyszłych rozdźwięków między przyszłymi dyskutantami ze strony Korony i państwa litewskiego to kwestia, czy

\footnotetext{
25 G. Błaszczyk, Litwa na przełomie średniowiecza i nowożytności 1492-1569, Poznań 2002, s. $115-136$.

26 O. Halecki, Dzieje unii jagiellońskiej, t. II: W XVI wieku, opr. K. Błachowska, Warszawa 2013, s. $152-153$.

27 Sejm walny piotrkowski A. D. 1562, [w:] Źrzódłopisma do dziejów unii Korony Polskiej i Wielkiego Księstwa Litewskiego, cz. II, wyd. T. Działyński, Poznań 1856, s. 102-104.
} 
po unii mają istnieć dwa organizmy polityczne, czy też nie? W tym zawierało się między innymi dążenie elit politycznych Wielkiego Księstwa do zachowania odrębności sejmu litewskiego, przy akceptacji dla parlamentu wspólnego.

Do otwartej dyskusji na temat kształtu unii doszło podczas koronnego sejmu warszawskiego odbywającego się na przełomie 1563 i 1564 r. W obradach wzięła udział delegacja Wielkiego Księstwa Litewskiego, umocowana do rozmów uchwałą majowego sejmu wileńskiego z $1563 \mathrm{r}^{28} \mathrm{Na}$ jej czele stał Mikołaj Radziwiłł „Czarny”. On też wypowiadał się jako reprezentant elit litewskich. W składzie delegacji litewskiej znajdował się także Mikołaj Radziwiłł, starszy syn Mikołaja Radziwiłła „Rudego”29, jako przedstawiciel rycerstwa litewskiego.

Przebieg dyskusji jest bardzo ciekawy, wskazujący, iż nie tylko Litwini „dojrzewali" do kompromisu w kwestii związku obu państw, ale i polskie elity polityczne $\mathrm{z}$ senatu, ale i z izby poselskiej, podczas obrad przechodziły ewolucję w sposobie myślenia o przyszłej unii ${ }^{30}$. O poglądach elit koronnych na temat związku z Wielkim Księstwem wiele mówią wygłoszone wówczas wota senatorskie. W początkowej fazie rozmów o unii, 7 stycznia 1564 r. Walenty Dembiński, podskarbi wielki koronny, powiedział między innymi: „A przeto ma li być Unia, niechaj one ziemie wszystkie zwane będą Nową Polską, a przed się jedną Koroną są". Natomiast Filip Padniewski, biskup krakowski, tego samego dnia w swoim wotum dodał: „Nie utracajmyż tedy tego potomkom naszym, co dawno przodkowie nasi zebrali, a przy tem się baczymy, że się za Litwą zakrywa Wołyń, Łucko i Podlasze, na których dzierżawach urzędnicy bywali z domów tych przedniejszych: Tarnowskiego, Tęczyńskiego, Zborowskiego, Polacy i Koronie z nich respondowali” ${ }^{31}$. Przy wyraźnym nakreśleniu przez wystąpienia Mikołaja Radziwiłła „Czarnego” intencji elit możnowładczych litewskich, zmierzających przede wszystkim do zabezpieczenia pomocy koronnej w walce ze wschodnim sąsiadem i konsekwentnie dążących do zachowania możliwie jak najdalej idącej odrębności Wielkiego Księstwa Litewskiego, niezbędna stawała się mediacyjna rola panującego. Od tego momentu działania Zygmunta Augusta w dążeniu do takiego kształtu unii, który zabezpieczałby w przyszłości bezpieczeństwo państwa litewskiego, a w drugiej kolejności państwa polskiego, plasują go w poczcie mężów stanu. Myślenie kategoriami państwa stanie się odtąd stałym motywem jego działań. Nie powinny przesłaniać

\footnotetext{
28 O. Halecki, op. cit. s. 164-166.

29 H. Lulewicz, Radziwiłt Mikołaj, h. Trąby (ok. 1546-1589), łowczy litewski, później wojewoda nowogródzki, [w:] PSB, t. 30, s. 347-349.

30 Nie może być tu miejsca na szczegółowy opis przebiegu dyskusji. Czytelnik może się zapoznać z przebiegiem obrad dzięki wydanemu drukiem przez Tytusa Działyńskiego diariuszowi sejmowemu, bądź innego autorstwa diariuszowi obrad tego sejmu, zamieszczonym w B. Czart. 1622.

31 Warszawski sejm Anno Domini 1563, [w:] Źrzódłopisma..., s. 272, 273.
} 
tego faktu mało chlubne obyczaje istniejące na dworze monarszym w końcówce jego życia.

Podczas obrad sejmu warszawskiego 1563/1564 nie doszło do pełnego porozumienia między Polakami i Litwinami w kwestii kształtu przyszłej unii. Dużą przeszkodą było zdominowanie grupy delegacji litewskiej przez Mikołaja Radziwiłła „Czarnego”, który nie dopuścił do ujawnienia innych litewskich opcji kształtu unii. Ale także przeszkodą były drobiazgi wnoszone przez senatorów i posłów polskich. Na przykład otwarty punkt do przyszłego kompromisu wypłynął ze strony polskiej: szlachta przychyliła się wprawdzie do koncepcji odrębności centralnych urzędów państwowych ${ }^{32}$, jednak sprawa rozbiła się o tytulaturę. Koroniarze uparli się, by przy zachowaniu odrębności urzędów tytuły ich brzmiały: „Kanclerz Koronny per Lituaniam, nie Magni Ducatus, pieczęć także Koronna, orzeł, ad instar pieczęci Koronnej (...) Marszałek także Koronny per Lituaniam" 33 . Wydawało się wszelako, iż porozumienie jest bliskie, zważywszy, iż Litwini zgodzili się w końcu, by wspólna elekcja nie była ograniczana przez prawa dynastyczne, a sejmy były odtąd zgromadzeniami wspólnymi. Postanowiono spisać dotychczasowe uzgodnienia. I w tym momencie doszła informacja o zwycięstwie wojsk litewsko-polskich pod Ułą (2 lutego 1564 r.). Litwini wycofali się wówczas częściowo z wypracowanego kompromisu. Widać to w rezolucji podjętej 9 lutego $^{34}$. Późniejszy brak akceptacji Mikołaja Radziwiłła „Czarnego” także i tej rezolucji ukrócił Zygmunt August, zrzekając się oficjalnie praw sukcesyjnych do Wielkiego Księstwa i przelewając je na Koronę oraz usuwając różnice ustrojowe poprzez wprowadzenie systemu sejmikowego w Księstwie i sądownictwo ziemskie na wzór polski.

Niezależnie od efektów końcowych tego sejmu w zakresie wypracowania kształtu unii dyskusja podczas jego obrad była bardzo potrzebna i przygotowała jej ostateczny kształt.

Opór przeciwko zacieśnieniu więzi między obu państwami jagiellońskimi obu braci Radziwiłłów widoczny jest podczas starań króla o skłonienie ich do uczestnictwa w litewskim sejmie w Bielsku, w maju 1564 r. Dyskusja między panującym i braćmi, opisana na podstawie korespondencji radziwiłłowskiej przez Marka Ferenca, wskazuje, iż dla relacji między Mikołajem Radziwiłłem „Czarnym" a Zygmuntem był to rok przełomowy we wzajemnych relacjach. Radziwiłł wyraźnie przechodził do opozycji wobec panującego ${ }^{35}$. Litewski sejm w Bielsku, przygotowujący zmianę w sądownictwie ziemskim na wzór systemu sądownictwa w Polsce, zakończyło opracowanie litewskiego stanowiska w sprawie unii. Miały

\footnotetext{
32 Ibidem, s. 328.

33 Ibidem.

34 Ibidem, s. 349-350.

35 M. Ferenc, op. cit., s. 274.
} 
zostać zachowane odrębne urzędy dla Koroniarzy i Litwinów, sejmy miały być wspólne, jednak odbywać się miały naprzemiennie w obu państwach. Wielkiego Księstwa Litewskiego miała nie dotyczyć egzekucja praw, a Zygmunt August obiecał zrzeczenie się swoich praw dziedzicznych do Wielkiego Księstwa i przelanie ich nie tylko na Polaków, ale i na Litwinów. Kompromis ten miał skutkować zawarciem unii na nadchodzącym wspólnym sejmie w Parczewie ${ }^{36}$. Litwini jednak przysłali nań jedynie delegację, z zastrzeżeniem, iż dokumenty powstałe na sejmie bielskim w sprawie unii nie są ostateczne.

Zrozumiała i uzasadniona była zmiana stanowiska króla wobec problemów unifikacyjnych państw, które łączył pod swoim berłem. Brak nadziei na męskiego potomka z małżeństwa z Katarzyną Habsburżanką, przy luźnym związku obu państw jagiellońskich, stawiał pod znakiem zapytania pomoc Polski dla Księstwa Litewskiego po śmierci ostatniego Jagiellona. Postawę króla wobec tej kwestii cechował pragmatyzm, u podłoża którego leżała troska o przyszłość Wielkiego Księstwa Litewskiego. Rozumiejąc przywiązanie Litwinów do tradycji państwowej i kulturowej, i własnej odrębności, wyciszał nadmierne ambicje koronnych kręgów szlacheckich dążących do wcielenia Wielkiego Księstwa do Korony i stworzenia tzw. Nowej Polski.

Sejm unijny trwał od 10 stycznia do 12 sierpnia 1569 r. W pierwszym okresie (do ucieczki Litwinów, w nocy z 28 lutego na 1 marca 1569 r.) obie strony przedstawiły swoje własne koncepcji unii. Polacy zrezygnowali z włączenia państwa litewskiego w skład Korony. Nie chcieli jednak odstąpić od koncepcji wspólnego sejmu, wspólnej elekcji, wyrażali zgodę na odrębne urzędy dla obu państw jagiellońskich. Stanowisko litewskie szło w kierunku takiego kształtu związku obu państw, który przypominał przymierze wojskowe. Po wyjeździe delegacji litewskiej Zygmunt August inkorporował do Polski Podlasie (5 marca 1569 r.), 27 maja włączony został do Korony Wołyń z Bracławszczyzną, a 6 czerwca 1569 r. nastąpił akt inkorporacji Kijowszczyzny ${ }^{37}$. W okresie tym powstał nowy projekt unii, będący poniekąd powtórzeniem porozumienia z obrad sejmu 1563/1564 r. Miały być wspólne sejmy, odrębne urzędy, sądy i prawo, przy zachowaniu porozumienia wojskowego (co zawierało się także we wspólnej polityce zagranicznej). Inkorporacje spornych ziem i wysunięty przez Polaków projekt nowej formy związku obu państw wywołał ogromne wzburzenie w Wielkim Księstwie. Mimo to zwyciężyła na zjeździe w Wilnie 20 marca 1569 r. grupa skłonna do kompromisu i powrotu do Lublina. Mikołaj Radziwiłł „Rudy" nadal miał jednak nadzieję na weryfikację programu unifikacyjnego wysuniętego przez Koroniarzy. W liście z 5 maja pisze o zwołanym przez Zygmunta Augusta na 10 maja sejmiku przedsejmowym w Wilnie, na którym panowie li-

\footnotetext{
36 Sejm walny parczewski 1564 r., [w:] VC, t. II: 1550-1609, vol. 1: 1550-1585, s. 154-159.

37 G. Błaszczyk, op. cit., s. 146-156.
} 
tewscy mieli ostatecznie zadecydować o tym, czy powrócić do Lublina, czy nie. Brak zgody Mikołaja Radziwiłła „Rudego” na proponowany przez Koroniarzy unifikacyjny program widoczne są w jego liście z 16 maja, kiedy domaga się odnalezienia przez bratanka przywileju króla Aleksandra Jagiellończyka i rzekomego przywileju królewicza Fryderyka. Zapewne oczekiwał, iż znajdują się one w archiwum radziwiłłowskim, będącym w posiadaniu Mikołaja Krzysztofa „Sierotki”. Jego ojciec, jak wspomniano, przechowywał przywileje państwa litewskiego. Negocjacje z królem po wyjeździe z Lublina prowadził Mikołaj Radziwiłł „Rudy” przy pomocy oddanego sobie długoletniego klienta i sekretarza, Andrzeja Wolana. List Wolana z Lublina, z 31 maja 1569 r. ${ }^{38}$, pozwala zrozumieć dylematy, jakie miał wojewoda ze swoim dawnym szwagrem w przeddzień podpisania aktu unijnego. Pokazuje też realne zagrożenie utraty dóbr wołyńskich i podlaskich przez Mikołaja Krzysztofa Radziwiłła „Sierotkę”, gdyby wojewodzic wileński nie złożył z tych dóbr przysięgi: „Bo y od Pana Wojewodzica Wileńskiego wszystkie imiona na Wołyniu i Podlassiu odsądzić miano, asz dzisieiszą nocą przibieżał, i podobno dziś przysięgać będzie"39. I rzeczywiście, jak wynika z dalszej części korespondencji, najstarszy bratanek Mikołaja Radziwiłła „Rudego" złożył Koronie przysięgę z radziwiłłowskich dóbr wołyńskich i podlaskich 31 maja $1569 \mathrm{r}$.

Litwini wrócili na obrady do Lublina 7 czerwca. Doszło do kompromisu. Ostateczny tekst unii został opracowany przez Franciszka Krasińskiego, podkanclerzego koronnego. Jak wiadomo, akt unii został podpisany 1 lipca $1569 \mathrm{r}$.

Prezentowana korespondencja jest jedynie fragmentem zbioru. Są to kolejno wysyłane przez Mikołaja Radziwiłła „Rudego” listy we wskazanym w tytule czasie. Brak jest wprawdzie odpowiedzi bratanka na listy stryja, jednak kolejne, następujące po sobie listy umożliwiają odtworzenie dialogu między obu bohaterami. Korespondencja zawiera wiele treści dotyczących wzajemnej relacji między wojewodą wileńskim a najstarszym synem jego brata, Mikołaja Radziwiłła „Czarnego”, Mikołajem Krzysztofem „Sierotką”. Prezentuje jednak przede wszystkim poglądy Mikołaja „Rudego” na temat realizacji nowego kształtu ustrojowo-politycznego obu państw, osoby odgrywającej po śmierci Mikołaja Radziwiłła „Czarnego” najważniejszą rolę w Wielkim Księstwie Litewskim. Wskazuje na poczucie rodowej dumy z dotychczasowych dokonań domu Radziwiłłów w życiu publicznym i militarnym państwa litewskiego. Jest także swoistą oceną kształtu unii z punktu widzenia części elit możnowładczych Wielkiego Księstwa Litewskiego. Oceną, która wypływała, zdaniem tej grupy, z troski o litewskie racje stanu.

Korespondencja jest też wyrazem więzi między bratankiem i stryjem, stosunków nie zawsze do końca mających znamiona szczerości. Przykładem jest

38 Andrzej Wolan do Mikołaja Radziwitła wojewody wileńskiego, z Lublina, 31 maja 1569 roku, [w:] S. Kot, Gniewy o unię, Kraków 1938, s. 5-9.

39 Ibidem, s. 8. 
choćby zapewnienie Mikołaja Radziwiłła „Rudego” o niszczeniu listów od bratanka z prośbą o wzajemność. Jak widać, Mikołaj Radziwiłł „Sierotka” nie okazał w tym momencie lojalności wobec stryja (na szczęście dla nas - listy przetrwały). Niewątpliwie jednak płaszczyzną ich wzajemnego wsparcia było w pierwszym rzędzie dobro domu Radziwiłłowskiego. W drugim - dobro Rzeczypospolitej Litewskiej.

\section{Rosyjska Biblioteka Narodowa (RNB), Sankt-Petersburg, Sobranije avtogra- fov P. P. Dubrovskogo, fond. 971, op. 2, d. 185, nr 234.}

\section{[k. 59] Fond 971, op. 2, d. 185, nr 234, k. 59-60: Mikołaj Radziwiłł wojewoda wileński do Mikołaja Krzysztofa Radziwiłła, z Woginia, 19 Decembris 1568.}

„Wielmożnemu panu Mikołajowi Krystofowi Radziwiłłowi księciu na Ołyce i Nieświeżu, grabi na Szydłowie, Panu i synowcowi memu łaskawemu. Do własnych rąk Jego Miłości.

Miłościwy panie wojewodzicze, Panie a synowcze mnie miły i łaskawy. Pewienem tego, że i WMść sam i pogotowiu mieszek WMści po ty wszystkie czasy ma co z sobą czynić. Wszakże z wielia przyczyn a co największa, z powinności mej krewnej ku WM. zdało mi się za słuszne to WM. napisać persuadując to WM., jakoż zaprawdę widzę to być rzecz bardzo WM. potrzebną, abyś WMść raczył przybyć sam do tego sejmu, a zjazdu Koruny z Księstwem Litewskim do Lublina, gdyżeś WMść ea familia et per gentile natus, którego przodkowie w tych akciech znacznie mianowani byli, abyś też i WM. acz nic, alie presentia sua okazał to w oczu sąsiadów naszych, żeć jeszcze z łaski Bożej w Litwie nie zeszło na potomstwie tych, którzy pierwej od dawnych czasów znaczni byli w Litwie starożytnością familiej Radziwiłłowskiej i naszej godnie, sławnie i uczciwie i pożytecznie służąc Rzeczypospolitej i onę na sobie dźwigając, na co i Rzeczy naszej pospolitej i pogotowiu familiej naszej Radziwiłłowskiej jako rozumieć mogę nie mało należy, i pewienem tego i WM. sam rozumieć raczysz co ja [k. 59v] puszczam meliori iudicio WM., a do tego aktu ku Lublinowi mógłbyś się WM. nie z wielką gromadą sług puścić. Ja, iż to piszę ku WM., rad to czynię, bom to powinien jakom wyżej napisał WM. Wierzę, że to WMść ode mnie jako stryja swego wdzięcznie przyjmować raczysz.

Nowin sam żadnych nie masz, jedno co i dawno posłowie nasi opirają się, aby do Lublina nie jachać, ale mym zdaniem nafrasowawszy przed się, o Lublin oprzeć będą chcieć, bośmy jako dawno między sobą swarni, chocia nam o wszystko i o ostatni szańc prawie idzie, a wżdy każdy w swą, a stawszy by się niebo i ziemia miała przewrócić co się tedy przed się tego ptaka unią do upaści dognać, tak nas Pan Bóg dotknąć raczył. Virga correctionis suae, a słusznie quia peccauimus in faciem Dei nostri. Wszakże w tymże samym nadzieja, 
że on jako Wszechmogący z miłosierdzia swego porriget nobis manu obrony swej Boskiej [k. 60] to WM. raczysz wiedzieć, którzy [jedno słowo nieczytelne] finem suae w Lublinie, do którego proszę, może li też w tym dla mnie stryja i sługi swego przybyć, abyś to WMść uczynić raczył. A iż widzę, że tego WM. grzywną jedną nie odprawisz, będę to chciał naprzód z powinności, krewnej, a potym i z takiej uczynności WM ku sobie, WM. też to tak zasługować i zadziaływać do każdej potrzeby WM. jachać, być ze wszystką majętnością, acz gdzie będzie wola i potrzeba WMści. Zatym życzę WM. od Pana Boga długo fortunnego zdrowia, łaskawej i powinnej się przyjaźni WM. pilnie zalecam.

Dat z Woginia, roku 1568, Decembris 19 die.

Wści życzliwy stryj Mikołaj Radziwiłł wojewoda wileński ręką swą" .

\section{Fond 971, op. 2, d. 185, nr 234, k. 61: Mikołaj Radziwiłł wojewoda wileński do Mikołaja Krzysztofa Radziwiłła, 24 grudnia 1568 r.}

„Wielmożnemu Panu Mikołajowi Krystofowi Radziwiłłowi książęciu na Ołyce i Nieświeżu wojewodzicowi wileńskiemu, Panu a synowcowi memu łaskawemu", 24 grudnia $1568 \mathrm{r}$.

Miłościwy Panie wojewodzicze, panie a synowcze mnie łaskawy.

Pisałem i posłałem był niedawno list mój ku WM., który jeśli WM. doszedł, będziesz WM. z niego wyrozumieć, żem WMści radził i teraz radzę, abyś WMść sam ku Jego Królewskiej Miłości do stanowienia tego spolnego aktu uniej przyjachać raczył, z wielia słusznych przyczyn, i z tej samej, że przodkowie WM. o tym akciej w takowych rzeczach radzili przed tym. Przeto abyś WM. przykładem ich sam przyjechać raczył pomoc być nam weselić dale nam Pan Bóg co dobrego postanowić na tem teraźniejszym spolnym sejmie. A jeśliby też, czego Boże uchowaj, co przeciwnego było, tedy abyś WMść nam pomógł tego nie trzymać.

$\mathrm{Na}$ ten czas nic nowego ku wiadomości WMści godnego nie mam. Jedno życząc WM od Pana Boga długo fortunnego zdrowia, łaskawej się przyjaźni WM zalecam.

Dat z Woginia, 24 Decembris 1568

WM życzliwy stryj

Mikołaj Radziwiłł wojewoda wileński, manu pro[pria].

Fond 971, op. 2, d. 185, nr 234, k. 63-64: Mikołaj Radziwiłł wojewoda wileński do Mikołaja Krzysztofa Radziwiłła, z Lublina, 1 stycznia 1569 r.

Wielmożnemu panu Mikołajowi Chrystophowi Radziwiłłowi książęciu na Ołyce i Nieświeżu wojewodzicowi wileńskiemu panu synowcowi mnie wielce miłemu i łaskawemu, z Lublina, January Anno Salutis 1569. 
Miłościwy panie Wojewodzicze Panie a Synowcze mój łaskawy.

Raczysz mi WMść pisać, obmawiając się, żeś WM. dawniej na siem do Lublina przyjechać nie raczył, tedy tej obmowy WMści ku mnie nie była potrzeba. Ale co się dotycze bycia WMści tego jest pilna potrzeba, abyś WMść niemieszkanie sam do Lublina przyjechać raczył i dla Gródka, i dla pana Mieleckiego ${ }^{40}$, jako mi i sam WMść o tym pisać raczysz.

A bodaj tak jest, żeby się lepiej było stało, gdzieby o tym gadano z panem Mieleckim, pierwej niż mu siostra WMści dana. Jakoż się to było zleciło panu Ostafiejowi ${ }^{41}$. Ale nad testament ${ }^{42}$ nie może nic wyciągać pan Mielecki.

Za wszystkie nowiny, któreś mi WMść bardzo potrzebnie oznajmić raczył, WM. pilnie a bardzo dziękuję, o czym coram latius da Bóg z WMością gadać będą. Alieć pana Jeronima Ossolińskiego ${ }^{43}$ owdzie w Lublinie jeszcze nie masz, i nie wiem będzie li.

Co mi WMść pisać raczysz, iż WMść od wielia liudzi to wiesz jakobych ja i z mieszkam i czym innym WMości niechęć swą pokazować miał nad zadziałanie WMości? Może to być, że się ktoś tym WM. przysługuje, widząc WMść pana młodego, a tak o WMści mnimając, że WMość pliotkam snadnie wierzyć raczysz. Alie ja inak o WMości i dzierżę i wierzę, że WMość wiedzą powinność moję ku WM., a WMości ku mnie, nie będziesz raczył nic innego o mnie rozumieć, jedno co masz rozumieć, o dobrym a życzliwym stryju, którą nie jedno

\footnotetext{
40 Mikołaj Mielecki, syn Anny i Jana, od 1566 r. mąż Elżbiety Radziwiłłówny, najstarszej córki Mikołaja Radziwiłła „Czarnego”, siostry Mikołaja Krzysztofa Radziwiłła. Od 1567 r. kasztelan wojnicki, a od września 1569 r., wojewoda podolski, zob. H. Kowalska, Mielecki Mikołaj, h. Gryf (zm. 1585), wojewoda podolski, hetman wielki koronny, [w:] PSB, t. 20, s. 759-765; T. Kempa, op. cit., s. 46.

41 Prawdopodobnie chodzi o Ostafa (Eustachego) Wołłowicza, pisarza wojewody wileńskiego (Mikołaja Radziwiłła „Czarnego” w latach 1551-1565), marszałka hospodarskiego (od 1553 r.), marszałka nadwornego WKsL w latach 1561-1569, podkanclerzego WKsL w latach 1566-1579, kasztelana trockiego w latach 1569-1579, kasztelana wileńskiego i kanclerza WKsL w latach 1579-1587, zob. Urzędnicy Wielkiego Księstwa Litewskiego. Spisy, t. 2: województwo trockie XIV-XVIII wiek, red. A. Rachuba, oprac. H. Lulewicz i in., Warszawa 2009, s. 672; Urzędnicy Wielkiego Księstwa Litewskiego. Spisy, t. 1: województwo wileńskie XIV-XVIII wiek, red. A. Rachuba, oprac. H. Lulewicz i in., Warszawa 2004, s. 194.

42 Testament Mikołaja Czarnego Radziwiłła, [w:] J. Jasnowski, op. cit., s. 415-418; U. Augustyniak, op. cit., s. 16-21.

43 I. Kaniewska, Ossolinski Hieronim (Jarosz), h. Topór (zm. między 1575 a 1576), poset sejmowy, działacz reformacyjny, kasztelan sandomierski, [w:] PSB, t. 24, s. 396-399. Hieronim Ossoliński był prawdopodobnie autorem utworu pt. De unione Lithuaniae, przybliżającego szlachcie dzieje unii jagiellońskich, podkreślającego przy tym, iż głównym czynnikiem nieegzekwowania zasad unii zawieranych między obu państwami był fakt naruszania wspólnej elekcji, zob. O. Halecki, op. cit., s. 138. Hieronim Ossoliński mógł być wspominany w tym momencie także z powodu kłopotu, jaki miał Mikołaj Krzysztof „Sierotka” z powierzeniem opieki nad niedorosłymi trzema siostrami. Dotychczasowa ich opiekunka bowiem, Zofia z Odrowążów Tarnowska, chorowała, a w podróży opiekować się miał nimi Hieronim Ossoliński, zob. M. Ferenc, op. cit., s. 41.
} 
WMościom powinowatym swym, ale też i obcym wiem jako się zachować mam statecznością przyjaźni swej.

A krótce ci powiadacze, którzy to WMości powiadali, nie tuszę [k. 63v] by sobie jaki pożytek, na który podobno trwają pliotkami swemi odzierżeli, kiedy to WMość poznasz i obaczysz, alie owie nie rękami namacasz w krótkim czasie, że oni bajki to o mnie stroją.

A też nie dziw złym ludziom między powinne nieprzyjaźń siać, jedno liudzie stateczni a baczni tedy więc wiedzą jako u siebie poważać i przyjmować mają powieści płonne, i z tym teraz dobyć, sam więcej będą gadał z WMością.

Ale być do tego czuję, żem tym jest i takim stryjem i przyjacielem WM. jakim powinność moja mnie uczy i wiedzie do tego.

O sługę WMości Kunińskiego ${ }^{44}$, tak jest, żem to mówił przed jednym sługą WM., kiedy nadprzegrawszy prawa WM. do strony przeciwnej około długu z Hlebowiczową, dopiro do mnie się uciekł o pomoc i radę. Jakożem ja przedbyę [?] rzeczy prawem upuszczonej do Lublina przyjachawszy nieco z strony WM. pomógł. Alie mię to boliało od sługi WMści, że mi to po hejnale opowiedział. I powiedziałem to, jeśliś to czynił radą pierwej Kunińskiego, i dopiero upuściwszy, każesz mi zbierać, tegom był żałościw.

$\mathrm{K}$ temu, żem to tak zasłychnął, czemu do końca nie wierzę, że Kuniński miał WMści ukazować panu swemu gdzieś drogę indzie do ufności WMości, o przyjaźni czyjejś mojej cudzej mimo mojej krewną, a dali Bóg stateczną. Co jeśli Kuniński czynił, źle się na to rozmyślił. Wszakże jeszcze ja i temu o nim nie do końca wierzę. A o WMości pewnie dzierżę, że się WMość będąc krewnym moim a panem bacznym, chociaby tak było, na takich się radach bez dobrego rozmysłu nie będziesz sadził. Przeto tym to zawieram, że ja wiem jako być kochan z krewności mej z WMością. Dzierżę też to o WMości, że WMość będziesz wdzięczen przyjaźni mej powinnej.

[k. 64] O Gródek, chociaż WMość jeszcze nie przyjechał, jużem ja sam nie zaniechał mówić z królem, i będę WMości w tym służył jako dobry stryj synowcowi swemu będzie li WMość tego ode mnie wdzięczen. A chocia być też WMość wdzięczen nie był tego ode mnie o WMści nie dzierżę, tedy mi to Bóg będzie płacił, że ja krewne swe miłuję, i wszystkiego dobrego im życzę. Jakoż dali Bóg WMości i braci WMości wiecznie życzyć chcę.

Po napisaniu tego WMości listu ku mnie residuum co mi WMość pisać raczył. Naprzód o tych rozmowach, któreś WMość miał w Polszcze około executiej, to jako wyżej, też i teraz WMości za to dziękuję, a coram latius o tym gadać, dali Bóg będziemy z sobą.

\footnotetext{
44 Prawdopodobnie chodzi o Wojciecha Kunińskiego, jednego z zarządzających dobrami radziwiłłowskimi urzędników, którzy pełnili swoje obowiązki jeszcze podczas życia Mikołaja Radziwiłła „Czarnego”, zob. T. Kempa, op. cit., s. 204.
} 
O pana z Tęczyna ${ }^{45}$, że mię tak przyjacielskie przed WMością spomniał, bardzo WMości dziękuję, że mię WMość przestrzegł, tym się ja życzliwiej o to u niego starać będę, aby przy mnie został przeciw Słuckiemu, który iż drzewa i zbroję z sobą wiezie, wiera nie źle czyni, bo sam o drwa trudno, więc drzewy może sobie w piecu palić. Zbroją też pewnie kogo opatrzy, kiedy ją słuczanie $\mathrm{z}$ siebie będą miotać, bo w niej niezwykli chodzić. A też nie wiem na kogo ją będzie po fili kładł. Bo Jego Mość ignobiles boiarones Słucenses wyjadłszy suchy chlieb z pałuby, bardzo się do domu kwapią ${ }^{46}$.

Quod restat, iż mi się WMość obmawiasz z tego pisania swego ku mnie, któreś WMość uczynił słysząc od kogoś o jakiejś niechęci mej, której ja, Bóg zna w sobie ku WMości nie czuję i nie znam. Tak ci przystoi przyjaciołom, zwłaszcza powinowatym ku sobie sincere wszystko peragere, a też to za łaską Bożą natura familiey naszej Radziwiłłowskiej dała, że co w sercu, to w uściech, Jedno wżdy uczciwszy osobę [k. 64v] WMości łgarzom wierzyć nie zwykli. Ergo, i ja tak to pisanie od WMości przyjmuję, jako mi się z niego WMość obmawiać raczysz. Ergo proszę, nie rozumiej WMość o mnie nic innego, jedno to co masz rozumieć o dobrym, cnotliwym krewnym, a stryju swym, i bracią swą, jako panowie synowcy moi mili.

Za tym życząc WMości od pana Boga dobrego zdrowia powinnej się przyjaźni WM zalecam.

Dat z Lublina, January Anno Salutis 1569

[własnoręcznie] WMości życzliwy stryj

Mikołaj Radziwiłł m[anu] p[ropria].

[k. 65-65v] [Kontynuacją tego listu jest bardzo nieczytelny własnoręczny dopisek Mikołaja Radziwiłła z 28 lutego 1569 r., z którego wynika, że Litwini planują opuszczenie Lublina, a o przyczynach tego odjazdu wojewoda wileński nie chce pisać, lecz pragnie na ten temat porozmawiać z Mikołajem Krzysztofem osobiście].

45 Prawdopodobnie chodzi o Jana Tęczyńskiego, w owym czasie starostę lubelskiego, w latach 1571-1593 kasztelana wojnickiego, od 1574 r. podkomorzego nadwornego i koronnego, zob. Urzędnicy województwa krakowskiego XVI-XVIII wieku. Spisy, red. A. Gąsiorowski, oprac. S. Cynarski, A. Falniowska-Gradowska, Kórnik 1990, s. 266.

46 Chodzi o książąt Olelkowiczów Słuckich (Jerzego, Symeona i Aleksandra), synów Jerzego Semenowicza Olelkowicza Słuckiego i Katarzyny z Tęczyńskich, o których ojcu już Mikołaj Radziwiłł „Czarny” pisał w liście do brata w 1551 r., że „chocia dureń, ale książę wielkie”, za: M. Ferenc, op. cit., s. 146. W 1569 r. Mikołaj Radziwiłł „Rudy” był w konflikcie z książętami Olelkowiczami Słuckimi (przede wszystkim z najstarszym, Jerzym, pełnoletnim, co do miejsca w radzie (senacie) litewskiej. Hierarchia zasiadania poszczególnych osób była omawiana w związku z projektem unii wypływającym ze strony elit litewskich. Tradycyjnie, Olelkowicze jako spokrewnieni z Jagiellonami, do 1560 r. zasiadali w radzie wielkoksiążęcej po biskupie wileńskim. 20 stycznia 1560 r., na skutek nacisków Mikołaja Radziwiłła „Czarnego”, wielki książę litewski przyznał to miejsce wojewodom wileńskim, zob. M. Ferenc, op. cit., s. 348-349. 
F. 971, op. 2, d. 185, nr 234, k. 67: Mikołaj Radziwiłł wojewoda wileński do Mikołaja Krzysztofa Radziwiłła, z Wilna, 4 kwietnia 1569 r. $1569 "$.

„Mikołaj Radziwiłł do Mikołaja Krysztofa Radziwiłła, z Wilna, 4 Aprilis

Miłościwy panie wojewodzicze, Panie a synowcze mój łaskawy.

Służby swe WMości wskazuję zdrowia WM. tym moim pisaniem nawiedzam.

Racz WMość wiedzieć, że chociam był miał na święta w Wilnie być ${ }^{47}$, tedy już być nie mogę, ale we Dubinkach, imieniu swym, siedm mil od Wilna być muszę. Ale i zaś skoro po świętach najdalej we śrzodę rano w Wilnie będę. Przeto miał li być WM. ku świętom do Wilna dla mnie przyjeżdżać, może się WMość przez święta tam na miejscu pozadzierżeć. Zatym się łaskawej i powinnej przyjaźni WM zalecam. Dan z Wilna, 4 Aprilis 1569.

WMości życzliwy stryj Mikołaj Radziwiłł wojewoda wileński.

[k. 69] Proszę pilnie jeślibyś WM nie miał być w Wilnie na święta, tedy racz WM we śrzodę skoro po święcie bo się mam w niektórych pilnych potrzebach z WMością namówić.

Fond 971, op. 2, d. 185, nr 234, k. 70-70v: Mikołaj Radziwiłł do Mikołaja Krzysztofa Radziwiłla, z Wilna, 26 kwietnia 1569 r.

„Wielmożnemu panu panu Mikołajowi Krysztofowi Radziwiłłowi książęciu na Ołyce, Nieświeżu, grabi na Szydłowcu, panu a synowcowi mnie łaskawemu, do własnych rąk ku czytaniu".

Miłościwy Panie Radziwille, Panie i synowcze mój wielce łaskawy.

Iż mi się trafił poseł pewny, sługa Jego Mości Pana podskarbiego ${ }^{48}$, nie chciałem go puścić do WMości bez tego mego listu, w którym winszuję, życzę WM. od Pana Boga dobrego zdrowia, społem z pany braćmi WM.

$\mathrm{K}$ temu racz WM. wiedzieć, że ten koń, któregom WM. obiecał i panu bratu WM., panu Jerzemu drugi pierwej około wód wielkich, nie mogli z nimi do Wilna przyjechać, a teraz po wyjechaniu WMości pilnie przywiedli mi je do Wilna. Przeto proszę nie miej mi WM. tego za złe, że mi ze trzy dni z drogi odpocząwszy do WM. je poślę. Panu Albrechtowi i Panu Stanisławowi o inochodniczki staram, które chocia potem poślę Ichmościom.

\footnotetext{
47 Wielkanoc w 1569 r. rozpoczynała się 4 kwietnia, zob. B. Włodarski, Chronologia polska, Warszawa 1957, s. 343.

48 Mogło chodzić albo o sługę Mikołaja Naruszewicza, podskarbiego ziemskiego w latach 1566-1575, albo sługę Ławryna (Wawrzyńca) Wojny, podskarbiego dwornego od stycznia 1569 do 1576 r., zob. Urzędnicy centralni i dostojnicy Wielkiego Księstwa Litewskiego XIV-XVIII wieku. Spisy, oprac. H. Lulewicz, A. Rachuba, Kórnik 1994, s. 156, 160.
} 
To mię też zaleciało z Lublina, że WMość masz listy mieć teraz, a jeden podobno od pana Ostafieja. Proszę pilnie WM., a bardzo proszę jednak, abyś WM. tego listu nikomu nie ukazywał, a zdrapał. Druga, iż mię tak zaleciało, że snać za WMść bodaj nie tenże wyżej pomieniony obiecuje królowi [k. 70v] żebyś WMść miał z Podlaskich imion swych Korunie przysięgę uczynić, czegom ja tak pewien jako dusznego zbawienia, że to nie będzie. Ale wżdy WMść w czas w tym przestrzegam. Co jeśli WMść tak dojdzie, jako mi dano znać, a będą li WMość do tego wieźć, tedy lepiej, iż WMść ode mnie wczas o tym wiedzieć będziesz raczył, by się na to rozmyślić, jako to będziesz miał odprawić. Ale i po wtóre, ja tak wierzę, i z tym umrę, że WMść nic innego czynić nie będziesz, w tej i w każdej innej mierze, jedno to co WMości przystoi, poczciwemu Radziwiłłowi, nie dając się w jeden regestr pisać z Kosińskim ${ }^{49}$.

Zatem repetitis vicibus miłości się powinnej y łasce WM. zalecam. Dat z Wilna, 26 Aprilis 1569. WMści stryj Mikołaj Radziwiłł wojewoda wileński $\mathrm{m}[\mathrm{anu}] \mathrm{p}$ [ropria].

\section{Fond 971, op. 2, d. 185, nr 234, k. 72-72v: Mikołaj Radziwiłł wojewoda wileński do Mikołaja Krzysztofa Radziwiłła, z Wilna, 5 maja 1569 r.}

„Jego Miłości panu Mikołajowi Krzysztofowi Radziwiłłowi książęciu na Ołyce i Nieświeżu, panu a synowcowi memu".

[k. 72] Miłościwy panie wojewodzicze, panie synowcze mój łaskawy.

$\mathrm{Z}$ młodum się tego jeszcze nauczył chować tajemnice przy sobie, kto mi się z czego zwierzy, takem i list WMości do mnie posłany, przeczytawszy, spalił. Co się dotycze pana Buczackiego ${ }^{50}$, temu odpiszę tak, jako mi WM. pisać raczył, i poślę mu ten list mój pacholiczkiem swym do Lublina, którego kopią do WM. poślę. Ale zaprawdę dziwni to nastali przyjaciele dzisiejszych czasów, że wszystko sobie folgują. A na przyjacielską potrzebę, utratę, nic nie baczą. Owa dawszy pannę jeszcze szukaj z nią panicza po świecie. Wiera to bardzo in conveniens, jako mi WM. sam o tym pisać raczysz. Przeto się mnie zda, abyś WM. tego pierwszego przedsięwzięcia swego odmieniać nie raczył, ani czasu, ani miejsca. Jakoż i ja nieco innego, alie i to z nim pisać będę, aby na ten czas, i na to miejsce to do Litwy po pannę jechał.

\footnotetext{
49 Adam Kosiński, jeden z posłów podlaskich, który przysięgał na wierność Koronie zaraz po wyjeździe Litwinów z Lublina i włączeniu Podlasia do Polski, zob. T. Kempa, op. cit., s. 55.

50 Prawdopodobnie chodzi o Mikołaja Buczackiego, podkomorzego kamienieckiego, przyszłego (od 1 października 1570 r.) męża jednej z sióstr Mikołaja Krzysztofa „Sierotki”, Anny (urodzonej w 1553 r.). Podczas obrad sejmowych Mikołaj Krzysztof Radziwiłł „Sierotka” miał się umówić co do spłaty posagu, wyprawy i terminu ślubu dwóch sióstr, wspomnianej Anny, i Zofii, przyszłej żony Achacego Czemy, wojewody pomorskiego, zob. ibidem, s. 25, 46, 52, 218.
} 
Pomnę też, że WMość w Wilnie będąc ze mną mówić raczył, abych pytał od siebie do pani koniuszynej Kozińskiej ${ }^{51}$ i do pana Łaskiego krajczego ${ }^{52}$ w potrzebie WM. o którejeś WM. ze mną mówił, jednom i ja przez WM. o to pytan, i WM. nic mnie nie oznajmił, jeśli ty listy do WM. mam posłać, czyli do nich. Jako mi WM o tym oznajmisz, tedy ja tak uczynię.

A co mi WM. pisać raczył około Lublina, co WM. stamtąd zaliata, zwłaszcza około pisania WM. do króla, dla tego radzą WM. niektórzy tam jechać i obmowę uczynić [k. 72v] o to pisanie. Przeto WM. potrzebujesz ode mnie wiedzieć, jeślibyśmy tam, rada litewska do Lublina jachali. Chcąc jachanie nasze uprzedzić, poki byśmy też nie jachali, tedy i WM. nie chciałbyś tam kazać sobie zaprzęgać, co się mnie dobrze podoba. Jednakoż, iż na ten czas przecz to pacholę WM. własne o tym nie bez przyczyny odpisać nie mogę co WM. oznajmuję przecz. To jest $\mathrm{w}$ tym, że sam powiatowy sejmik król JMość raczył w Wilnie w tę przyszłą śrzodę 10 dnia maja, na którym będzie nie mało panów. A dopiero $\mathrm{z}$ tego sejmiku, który nie więcej trzech dni nigdy nie bywa, i teraz nie będzie, postanowimy wszyscy spolnie mamy li tam do Lublina jachać, albo nie. A to cożkolwiek postanowimy, w tej mierze, tedy o niedzieli przyszłej, albo o poniedziałku ode mnie WM. wiedzieć będziesz. Co ja WM. przez własne swe pacholę na podwodach dam znać WM. to racz zapewnie wiedzieć.

Zaczym życząc WM od pana Boga dobrego zdrowia, przyjaźni WM łaskawej, bratskiej pilnie zażyczam. Dat w Wilnie, 5 maja 1569 . WM stryj życzliwy Mikołaj Radziwiłł wojewoda wileński.

\section{F. 971, op.2, d. 185, nr 234, k. 74: Mikołaj Radziwiłł wojewoda wileński do Mikołaja Krzysztofa Radziwiłła, z Wilna, 16 maja 1569 r.}

[k. 74] Miłościwy panie Radziwille, panie a synowcze mój łaskawy.

Racz WM. wiedzieć, iż się owdzie srebro WM. nalazło, a złodziej, co je był ukradł będzie wisiał.

Przy tym pilnie, pilnie i jeszcze bardzo pilnie proszę, abyś WM kazawszy się doszukać przywilejów króla Alexandrowego abo Friderykowego, o którym onegda sam z WMścią mówił, raczył mi je bez wszego omieszkania, co najrychlej posłać, gdyż to jest rzecz ziemska, abych mi przywilejów na ten czas co

\footnotetext{
51 Postać niezidentyfikowana. Koniuszym koronnym w latach 1564-1574 był Jakub Piasecki. On także był koniuszym litewskim do 1569 r., zob. Urzędnicy centralni i nadworni Polski XIV-XVIII wieku. Spisy, red. A. Gąsiorowski, oprac. K. Chłapowski i in., Kórnik 1992, s. 59.

52 Mikołaj Łaski, krajczy koronny w latach 1558-1572, starosta malborski od 1564 r., zob. ibidem, s. 64. Łaski, w gronie innych Koroniarzy, pomagał Radziwiłłowi w niedopuszczeniu zasady w zapisach unii, by kniaziowie Olelkowicze Słuccy zasiadali w pounijnym senacie, zob. M. Ferenc, op. cit., s. 349.
} 
pilna potrzeba. Co ja WM wdzięcznie zasługiwać będę. Zatym życząc WM od pana Boga dobrego y długo fortunnego zdrowia, a łaskawej być przyjaźni WM zalecam.

Dat z Wilna, 16 May 1569. WM życzliwy stryj

Mikołaj Radziwiłł ręką swą.

\section{F. 971, op. 2, d. 185, nr 234, k. 76-78v: Mikołaj Radziwiłł wojewoda wileński do Mikołaja Krzysztofa Radziwiłła, z Wilna, 30 maja 1569 r.}

[k. 76] Miłościwy panie wojewodzicze, Panie a synowcze mój łaskawy.

Pilnie WMości dziękuję za te kopie, któreś mi WM posłać raczył, aczbych był woliał oryginały, ale gdy to nie może być, na tym się przestać musi, co być może.

Co się dotycze przysięgi WMści z dóbr wołyńskich, acz ci trudny to węzeł na mię WM. kłaść raczysz, Radziwiłł na Radziwiłła, gdyż Radziwiłłowie zawżdy z łaski Bożej, a przez warunek jego święty do tej doby więcej się oglądali ad benedictus [?] que utile. Ale, gdy wszyscy, rada zwłaszcza Księstwa Litewskiego, biskupi, wojewodowie, onej ziemie wołyńskiej smakowali i wprzęgli to sobie za dobre, a nieszkodliwe, sławie i mniemaniu swemu przysięgać Koronie, tym się tylko cieszę, iż nie WMść Radziwiłł ten harc począł, ale kto iny. Źleż przybijać, bo odstąpić za tą przysięgą ojczyzny, zwłaszcza tej, w której przodkowie twoi mój miły panie synowcze żywiąc, onę na ramionach swych nosili, strzegli, bronili, o niej radzili, tak jako ją cało nam potomstwu swemu zostawili, a niedaleko zaniechawszy innych przodków twoich, ociec własny WMości, a brat mój ten wszystkiego zaniechawszy a patria peregrynować auxilium [jeden wyraz nieczytelny] tym sposobem był gotów, czegom ja dobrze świadom, brat jego, i podobnych mu był tego pomógł, bo łatwiej dwom, niż jednemu wszystko [k. 76v] złe i dobre znosić było, aby tylko nie był przyczyną, a ja brat jego zguby Rzeczy swej pospolitej z nim.

Jedno iż WMość masz duo impedimenta, czemu tego per nunc czynić nie tak snadnie możesz, jako ociec twój. Jedna, że nie na tym miejscu będziesz, na którym on siedział, i nie tymi kluczmi władasz, w Rzeczy pospolitej swej, którym władał za swe cnotliwe zasługi cny ojciec twój, jednoś tylko priuata persona aczkolwiek poczciwego i starożytnego narodu w Litwie.

Druga, ociec WMości nie miał działu o Ołykę i Nieśwież ni z kim, bo mu był brat rodzony którego jednego miał, umarł ${ }^{53}$. Wolno mu było ze wszystkim swym kierować jako i kędy chciał. A WMość masz trzech bratów po sobie młodszych, którzy iż są jeszcze minorennes, przysięgać nie mogą, działu z WMością

\footnotetext{
53 Wspomniany Jan Radziwiłł, rodzony brat Mikołaja Radziwiłła „Czarnego”, M. Michalewiczowa, op. cit.
} 
imion ojczystych nie wzięli do tej doby. Nie wiedzieć komu z was cztyrzech Ołyka, komu by z Nieśwież, któremu by Kleck, Dusiata, Możniki dostaną. A jakoż przystojnie WMość teraz pod tymi jeszcze niedojrzałymi laty braci swej, nie mając z nimi pewnego a wiecznego działu imion. Przysięgać byś już te miał by na to był respekt pobożny, a sprawiedliwy zwierzchniego urzędu, to samo wedle Boga i bojaźni jego i sprawiedliwości świętej mogłoby candido iusteque WM od tego [k. 77] juramentu teraźniejszego z dóbr wołyńskich wyswobodzić, wolnym uczynić. Bo Mikołaj za Jurka pogotowiu, za Olbrachta y Stanisława swym sumnieniem twierdzić nic nie może mimo ich własne. Bo nie wiedzieć, kto z was czterech na Wołyniu dział liosem, albo prawem weźmie. A to Boże słowa nec pater filii, nec filius patris iniquitqtem fert. A toż pogotowiu frater fratris. Więc jako WM. ta przysięga $\mathrm{z}$ osoby WM. uczyniona żadnego scrupulum conscientiae uczynić by nie mogła diuino iure gdybyś teraz WM przysiągł, a potem by się Ołyka drugiemu bratu WM. dostała, to by tylko do działu, a do possessiey samego WM. dzierżenia Ołyki trwała. A Polacy od drugiego brata, który by ją dzierżał musieliby repetować znowu przysięgę. Więc i mu samym małoby teraz na przysiędze WM. Alie gdzie gwałt, upór, mus, a taki, który repugnat Bogu de praestito iuramento głowy naszej contra iura libertatesque nostris.

Nie wiem, co innego mam WMści radzić, jedno tym co się tu wyżej pomieniło, obmawiać się, przyjdzie ciągnąć rzemyk, poki go staje, u pana i u Polaków, tylko tego im nie odkrywając, żeby nie chcieli repetować przysięgę u brata, który by był na Ołyce [k. 77v]. A gdzieby rzemyczka nie stawało, już ja to panu Bogu w szafunek jego święty młodość lat WMości, a stateczność krwie uczciwej, a szlacheckiej i książęcej twej Radziwiłłowej synowca mego miłego poruczam. A sam jako grzeszny a niegodny starzec będę go o to prosił ut omnes conatus tuos, raczył rządzić duchem swym Bożym, duchem mądrości i stateczności. Wszakże i po wtóre, i po trzecie proszę, napominam, i wiernie radzę, poki możesz, abyś WM młodość swą popisał w oczu i uszu męskich mocną opoką, a nie trzciną tczą. Alie nie naprzód, ani w pośrzodku może li być jedno gdy wszstcy flexis genibus przysięgać będą, doradziwszy tego dobrze, że z dóbr tylko wołyńskich, przyjdzie też nie z chęci, ale z przymuszenia WMości toż uczynić, abyś nie stracił ojczyzny braci swojej i swej. Wszakże alta voce radzę proclamare i opowiedzieć się panu i wszystkim do przysięgi idąc, iż nie czynisz tego naprzód własną chucią swą, abyś miał przyświadczyć WMość Wołyń Koronie od Księstwa. K temu abyś nie miał tego w sobie czuć, żeś Radziwiłł a Litwin urodzony, a nie Podlasianin, ani Wołyniec i przeciwko Rzeczy swej Pospolitej Wielkiej Litewskiej gdzieś się WMość urodził, przysięgać nie raczysz, jedno z dóbr wołyńskich, gdyż wszyscy insi obywatele ziemie [k. 78] wołyńskiej to czynią. WMość też nie chęcią swą, ale zwierzchnością pańską czynisz.

Piszę ja do WMości jako stryj, a dali Bóg wiernie życzliwy do synowca swego, a Radziwiłł do Radziwiłła. Wszakże jeszcze by WMość przyszedłszy in medium posłów i rad Księstwa Litewskiego, którzy będą abo są w Lublinie, 
racz opowiedzieć, żebyś tego nie rad uczynił, chęcią swą, jedno in minus jeśli do tego przyjdzie, i tamże ich WMość proś, o radę wszystkich i o pomoc, aby WMości z tego wyzwolili. Bo będą li WMości do tego radzić przysiąc, nie zawadzi to WMości na potym, żeś rady ich WMość używał. Poki by nie raczyli tego czynić WM., proś ich WMość, aby a stantibus Polonis przed panem i przed nimi WMości z tego dźwignęli, podpierali i ratowali. A to WMości w czym pierwej niżby WMości do przysięgi przyszło.

A przy tym proszę, aby to pisanie moje tylko przy WMości samego wiadomości ostało, k temu też aby mi WMość raczył dawać znać o wszystkim, co się tam w Lublinie będzie działo, nie żałując dla mnie pacholęcia swego, na strawę onemu, i konia odeń jako pan a synowiec mój miły i łaskawy. Proszę też pilnie, abyś tam WMość służebnikowi memu Jędrzejowi Wolianowi ${ }^{54}[\mathrm{k}$. 78v] raczył we wszem łaskawie pomagać, a onemu powiadać co skąd WMość usłyszesz, także wszędy gdzie WM pojedziesz. Proszę racz go WM za sobą wciągać, dla tego abym też od niego wiedział co się tam toczyć będzie... Życząc WM od pana Boga dobrego y długo fortunnego zdrowia, powinnej się przyjaźni WM pilnie zalecam.

Dat z Wilna 30 May 1569 WM. życzliwy stryj, Mikołaj Radziwiłł wojewoda wileński. Manu propria.

\section{F. 971, op. 2, syg. 185, rkps 234, k. 80-81v: Mikołaj Radziwiłł wojewoda wileński do Mikołaja Krzysztofa Radziwiłła, z Wilna 1 czerwca 1569 r.}

[k. 80] Miłościwy panie Radziwille, panie a synowcze mój łaskawy.

Wyrozumiałem z pisania WMości byś był WMość na podwodach tam do Lublina nie przybieżał, żebyś się był vpsnął dóbr wołyńskich y podlaskich. Podlasie jako taka, ale Ołyczka nie lada grzanka, o którą iż każą przysięgać WMości, jużem ja o tej przysiędze WMości dał znać videre meum przez pacholę pana podskarbiego litewskiego, jako i którym sposobem, coś WMość miał czynić, jeślibyś WMość na persuasiey mey chciał przestawać. Ale podobno po obiedzie łyżka. A nie w czas to moje pisanie WMości doszło. Wszakże przysięgi widziałem, żeś WMość zbyć nie mógł, wszakże nie pisałem był com rozumiał, które pisanie moje chocia po harapie WMości doszło, abo dojdzie, racz ję WMość sobie przeczytać, proszę dla przyszłych czasów.

\footnotetext{
54 Andrzej Wolan, etnicznie Polak z pochodzenia, pisarz polityczny i religijny, sekretarz królewski, obywatel Wielkiego Księstwa Litewskiego, poseł na sejmy, klient Mikołaja Radziwiłła „Rudego", zob.: M. Baliński, Andrzej Wolan jego życie uczone i publiczne, [w:] M. Baliński, Pisma historyczne, t. III, Warszawa 1843, s. 8-24; J. Zawadzki, Andrzej Wolan, [w:] Węzet na imieniny Wielmożnego Jmci pana Stefana Bogustawa na Wolanie Wolana, obersztlejtenanta wojska WXLit. z własnymże przezacnej Jego rodowitości zaszczytów uczyniona, „Wizerunki i roztrząsania naukowe. Poczet naukowy drugi”, t. XVII, Wilno 1840, s. 95-104.
} 
A odprawiwszy ten chwalebny coronny act, a nasz litewski biedny, proszę jeśliże ma persuasia moja miejsce u WMości, dali Bóg życzliwemu i krewna, racz WMość vale dicere Lublinowi, nie używając tryumfów ani biesiad, z tymi, którzy się kochają z przepaści naszej Litewskiej, chociażby to nic nie wadziło. Alie iż dziś wilie maligna, tempa... rzeczy przeciwnych na świecie, nasiałyby po tym nie rzeczono Radziwiłł Rad że Księstwo Litewskie ginie, abo już zginęło. O toż WMości pilnie proszę panie synowcze, abyś WM. ten list spalił, żeby go nikt u WMości nie widział, i po wtóre proszę. Przy tym miłościwy Panie Radziwille, panie synowcze mój łaskawy poruczyłem coś około obmowy [k. 80v] w rzeczy swej z książęciem Słuckim z WMścią rozmawiać służebnikowi memu Andrzejowi Wolanowi duffając łasce i powinności krewnej WMości ku sobie i o to WMość prosić, co wierzę, że WMość dla mnie chętnie uczynić raczysz. Bo ja też nie jedno mówić w potrzebie WMościu, A też i głowy nastawiać jestem powinien i chcę rad przez potrzebę WMości.

Co mi Wmość piszesz, abym do Lublina jachał dla poratowania rzeczy pospolitej. Acz moj miły panie synowcze, toć bych ja rad uczynił nie jedno z targaniem zdrowia, swego, z choroby od Boga przepuszczonej, ale też poczciwą śmiercią bez choroby rad bych to zapieczętował, żebych rzecz pospolitą swą poratował. Jedno proszę, racz to WMość obaczyć, a dobrze w siebie poważyć synowcze moj miły, że trzema rzeczoma rzecz się pospolita przez obywatelie jej zawżdy zwykła ratować, jedną mądrą radą, w której, acz to czuję, żem nie przeliadował rozumem, ale widzę i [jeden wyraz nieczytelny] monere rozum miejsca też by nie miał. Ergo, też i moja rada. Druga, mocnym zastanowieniem w obronie swej rzeczy pospolitej. W czym jaka dziś między nami zgoda, to ślepy widzieć może. K temu by to widział sąsiad, tylko ogryzałoby mu się jeśli non in toto, tedy wżdy in parte nie patrząc na możność y bogactwo jego, a na małość i niedostatek swój. Ale iż coś trzeciego w to się przymieszało, przeciwko czemu więcej cyt niż no [?] dziś należy o trona do poszew floream musi, aby dosyć się stało [k. 81] Onym Bożym floream non tantum bonis sed et [jeden wyraz niecztelny]. Trzecia prawem nie wały, ani mury, ludzie wolni bywają muniti circumdati w używaniu spokojnem majętności, swobód, dziatek, żen swoich, co gdy się ultro pada zda mi się czwartej fortece nie masz. Więc ja nie mógł bych $\mathrm{z}$ niczym innym, jedno z tym wyżej pomienionymi rzeczoma tam do Lublina jechać. A iż widzę, że ten towar na tem lubelskim jarmarku [wyraz nieczytelny], nie wiem po czo bych tam innego jachać miał, jedno to sam czynić czem w drugich ganił. A to nie jest rzecz statecznego człowieka, aby wżdy jeszcze jachać ad moderationem quandam Alexandrowego przywileju, wiera bych się dał wieźć tam do Lublina, ale iż tam mię sam słuchy dochodzą, że snadź sąsiedzi nasi już mając Wołyń, Podliasze, nie chcą nie jedno moderatie Alexandra, ale i samego Alexandra tylko aby nasi ich unią już ichże pieczęcią zapieczętowana vigore conuentus liubelskiego wydana do Metryki i Statutu ich podobno wwiedziona i im promowaną tylko potwierdzali przysięgami. To już nie unią z nimi tworzyć, 
coby dawny Litwin z Polakiem czynić między sobą mieli, ale co Polak sobie utworzył na swe dobra, a moje złe, to ty Litwinie poprzysiąż, wyznaj, potwierdź jego zwierzchność nad sobą, a swoje poddaństwo jemu. A takiego musu, abo nieszczęścia mogę ja wybornie doma doczekać, nie targając zdrowia, i nie tracąc na to niepotrzebnie [k. 81v] majętności, bo diabłu się chce jednemu złego swego szukać, a nie człowiekowi. Wszakże jeśli WMość obaczysz, żeby była moderacia przywileju Alexandrowego, a dawaj mi WMość znać, jeśli będę zdrów, jeszcze bych się mógł dać wieść do tego. K temu, żeby nie był siem wywołany, niźli ja przyjadę, bo bych już przyjachał do przekupek po orzechy, gdzie by się seim wywołał.

Zatym życząc WMości od Pana Boga dobrego i długo fortunnego zdrowia powinny się przyjaźni i łasce WM. pilnie zalecam.

Dat z Wilna Juni 1 die Anno 1569.

Życzliwy stryj Mikołaj Radziwiłł wojewoda wileński 